\title{
A Case of Fatal Varicella Zoster Infection with Refractory Abdominal \\ Pain as An Early Symptom
}

\author{
Yoshihiro YAKUSHIJIN, Yoko MINAMOTO, Kiyonori TAKADA, Masaki OTSUKA, \\ Masaki YASUKAWA \& Shigeru FUJITA \\ From the First Department of Internal Medicine, Ehime University School of Medicine, Ehime. Japan.
}

(Received : July 28, 2003)

(Accepted : October 21, 2003)

Key words : disseminated varicella zoster virus infection, immunocompromised patient, abdominal pain

〔J. J. A. Inf. D. $78: 64 \sim 69,2004$ ]

\section{Introduction}

In economically developed countries over $95 \%$ of healthy adults have been exposed to varicella zoster virus (VZV) during childhood ${ }^{1)}$. Therefore, not only primary infection but also reactivation with VZV are considered to be quite benign, and little consideration is given to the concomitant morbidity and mortality. It is the adult patient, along with the immunocompromised patient of any age, however, who will suffer the highest mortality rate from the VZV infection ${ }^{2)-6)}$. One major investigation reported that infection with VZV occurred in $16.6 \%$ of bone marrow transplantation (BMT) patients and the mortality rate from visceral dissemination of $\mathrm{VZV}$ was $55 \%{ }^{7}$. Therefore, to know the clinical features of the disseminated VZV infection is very important for an early diagnosis. Here we report a case of a patient, a recipient of an allogeneic BMT, who presented with refractory abdominal pain that was caused by visceral VZV infection as an early symptom, and discuss the importance of early diagnosis, treatment, and prevention of the disseminated VZV infection to immunocompromised patients.

\section{Case Report}

A 36-year-old man with chronic myelogenous leukemia had undergone allogeneic BMT from a Japanese-American donor in July, 1998. After BMT he had developed an acute graft versus host disease (GVHD) reaction, and medical treatment was administered using cyclosporins and steroids. His immunosuppressive agents had been withdrawn smoothly, and his medical observation in an outpatient clinic had continued with $5 \mathrm{mg}$ of prednisolone administered daily. In April 1999, symptoms such as low grade fever, dry cough, and mucous erosion in his mouth appeared one after another. In the beginning of May, his emaciation ( $-10 \mathrm{~kg} / 3$ months) due to appetite loss had become obvious. Therefore, he had been admitted

The First Department of Internal Medicine, Ehime University School of Medicine. Onsen-gun, Shigenobu-cho, Ehime 7910295, Japan 
Fig. 1 Skin vesicles four days after the onset of stomachache. Small vesicles with blebs on trunk of the patient (A) (B). Intra-epithelial vesicles in a skin biopsy (HE staining, $\times 40)(\mathrm{C})$. Multinucleated giant cells expressed varicella zoster virus antigen (brown) (immunostaining with monoclonal antibody, Chemicon Int., against VZV glycoprotein I, $\times 40)(D)$.
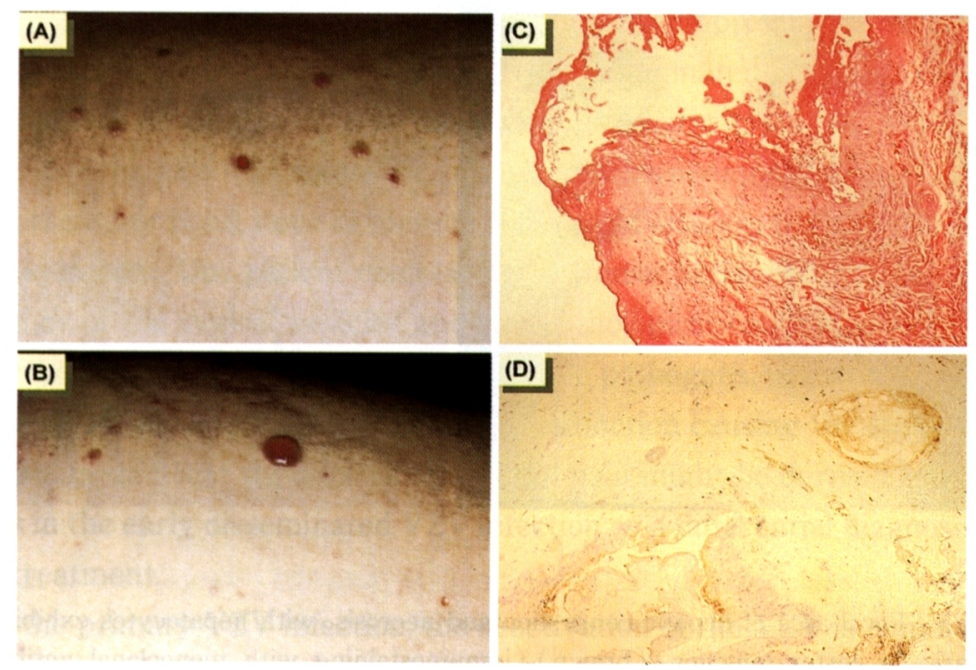

Table 1 Clinical course and laboratory findings

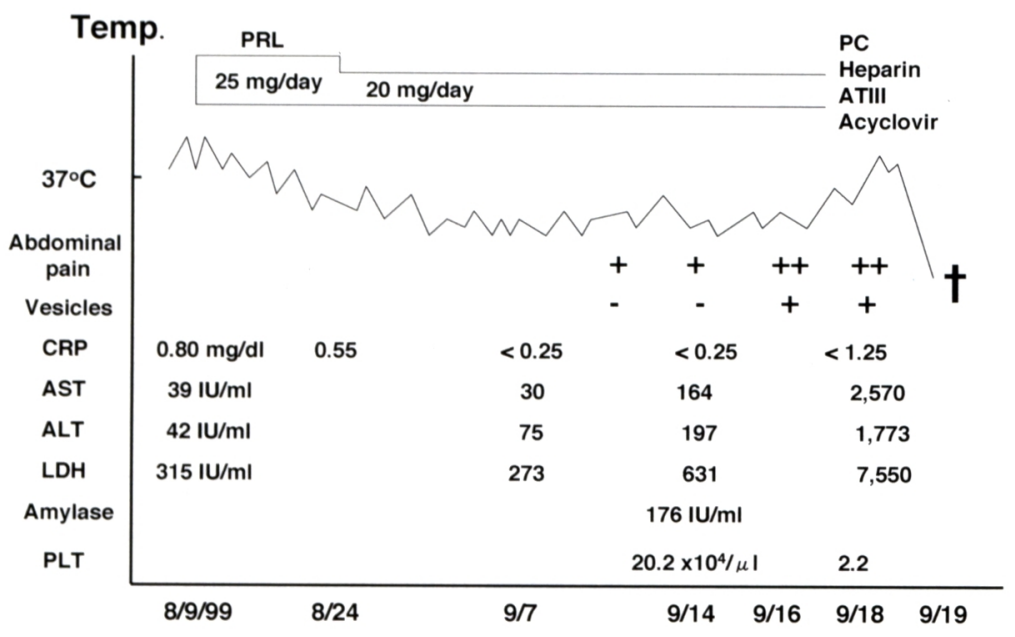

again and the medical treatment for his chronic GVHD had been started in August. Increased immunosuppressive agents improved the chronic GVHD, and 20mg of prednisolone daily was adopted as a maintenance dose on the 18th day of hospitalization. The patient's CRP changed to negative on September 1 , and his chronic GVHD was progressing well. Frequent stomach pains in his right hypochondrium occurred after the patient stayed overnight at his home on September 12. Although an electrocardiogram, chest and abdominal X-rays, ultrasonograpy, and endoscopic examination of the gastrointestinal tract were performed, the cause of his abdominal pain was unknown and remained unimproved. Small vesicles 
Fig. 2 Acute respiratory distress syndrome shown in chest X-ray (A) exhibiting diffuse alveolar damage (B) (HE staining, × 40).
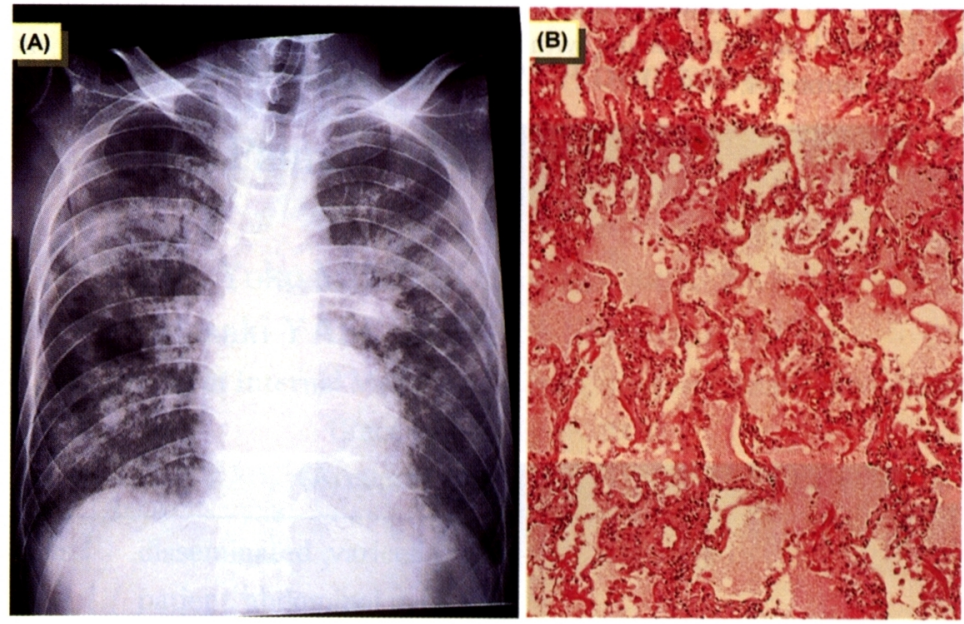

Fig. 3 Focal area of hepatic congestion and necrosis, with hepatocytes exhibiting varicella zoster infection (brown) (immunostaining with monoclonal antibody against VZV glycoprotein I) .
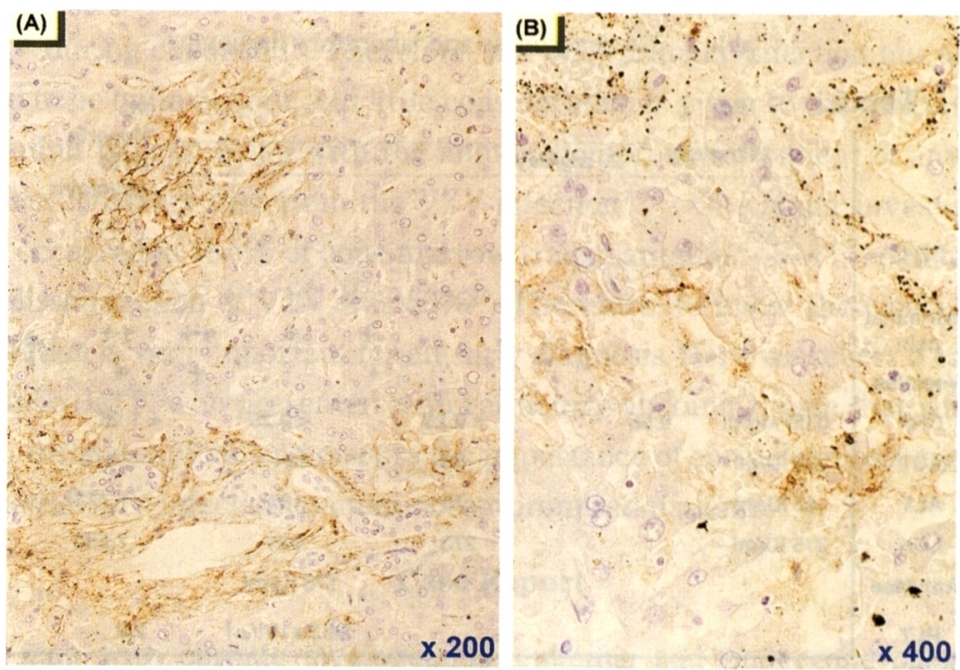

appeared suddenly on his face and trunk (Fig. 1) along with deterioration of liver function (Table 1) on September 16. A fluorescent antibody test detected VZV antigen in his bleb secretion, and he was finally diagnosed as having a disseminated VZV infection. The administration of acyclovir and $\gamma$ globulin preparations was started on September 16. However, he developed a pulmonary hemorrhage and gastrointestinal bleeding following disseminated intravascular coagulation on September 18. He died from acute respiratory distress syndrome (ARDS) (Fig. 2) on September 19 within three days after the diagnosis of the disseminated VZV infection. Liver necrosis with VZV infection (Fig. 3) and diffuse alveolar damage (Fig. 
2) were confirmed by autopsy.

\section{Discussion}

In this case presentation of fatal VZV infection, we demonstrated the importance of abdominal pain as an early presenting symptom of VZV infection in an immunocompromised patient. Several clinical investigators reported gastrointestinal complications of the disseminated VZV infection in recipients preceded by characteristic skin eruptions 4 and 10 days with in the first $2-10$ months after $\mathrm{BMT}^{8) \sim 12)}$. In the majority of these patients the pain was epigastric, occasionally involving the right upper quadrant or radiating to the back. On the other hand, none of these reports could address the clinico-pathological causes of the early abdominal symptom. Our patient complained of stomachache in his right hypochondrium four days before appearance of the typical vesicles and the pathological cause was not certain in the early stages. The VZV is considered to be one of the neurotropic pathogens, and our laboratory data, X-rays, and endoscopic examination did not show any organic dysfunction causing the stomachache. The lack of organic dysfunction suggested that this kind of abdominal pain might be derived from damage to the celiac nerve and plexus in the early disseminated VZV infection so a differential diagnosis is very important for determining the treatment.

Compared with the primary VZV infection, the reactivation of the VZV is common for immunocompromised adult patients, especially for recipients of hematopoietic stem cell transplants ${ }^{13)}$. The treatment and prevention of VZV infection should be a major consideration in the management of these recipients. Acyclovir, a DNA nucleoside analogue and one of the effective antiviral agents for the herpes virus, when given as a treatment for $\mathrm{VZV}$ infection, reduces the number of clinical and subclinical reactivations of VZV. Several reports indicated that oral or intravenous administration of acyclovir is an effective treatment for and prevention of the disseminated VZV infection in immunocompromised patients ${ }^{14) \sim 16)}$. Intravenous acyclovir is required for serious VZV infections but, for prevention, intravenous administration is not a common clinical procedure because of the high cost and long hospitalization time. On the other hand, oral ingestion of acyclovir is less effective than intravenous administration because of its poor absorption, low serum concentration, and short half-life ${ }^{17}$, suggesting that antiviral drugs still have a limited window of opportunity to affect the prevention of the VZV infection in immunocompromised patients.

The increased risk of VZV infection is mainly associated with diminished T-cell immunity to VZV but not with humoral immunity to VZV, since pretransplantation VZV IgG antibody titers are not predictive of risk or severity of $\mathrm{VZV}$ infection in BMT recipients ${ }^{18)}$. In many cases T-cell immunity to VZV is reestablished slowly after hematopoietic stem cell transplantation ${ }^{19)}$, and the efficacy of a post-transplant varicella vaccination in reducing the incidence of VZV infection is doubtful. However, some groups have reported on the efficacy of immunization after transplantation ${ }^{1320)}$. These reports suggest that T-cell mediated immunity is important to prevent disseminated VZV infection even for immunocompromised patients, and that effective immunization for VZV in immunocompromised patients should be considered because of the associated high morbidity and mortality rate.

In conclusion, this report focused on a case of fatal disseminated VZV infection after allogeneic BMT in an immunocompromised patient. Refractory stomachache is an important symptom for an early diagnosis of this VZV infection. 


\section{References}

1) Gershon AA : Live attenuated varicella vaccine. Annu Rev $1987 ; 38: 41-50$.

2) Weller TH : Varicella and herpes zoster : Changing concepts of the natural history, control, and importance of a not-sobenign virus. N Engl J Med $1983 ; 309: 1362-8$.

3) Locksley RM, Flournoy N, Sullivan KM, Meyers JD : Infection with varicella-zoster virus after marrow transplantation. J Infect Dis $1985 ; 152: 1172-81$.

4) Ljungman P, Lonnqvist B, Gahrton G, Ringden O, Sundqvist VA, Wahren B : Clinical and subclinical reactivation of varicella-zoster virus in immunocompromised patients. J Infect Dis $1986 ; 153: 840-7$.

5) Han CS, Miller W, Haake R, Weisdorf D : Varicella-zoster infection after bone marrow transplantation : Incidence. risk factors and complications. Bone Marrow Transplant $1994 ; 13: 277-83$.

6) Bilgrami S, Chakraborty NG, Pinero FR, Khan AM, Feingold JM, Bona RD, et al . : Varicella-zoster virus infection associated with high-dose chemotherapy and autologous stem-cell rescue. Bone Marrow Transplant $1999 ; 23: 469-74$.

7) Schiller GJ, Nimer SD, Gajewski JL, Golde DW : Abdominal presentation of varicella-zoster infection in recipients of allogeneic bone marrow transplantation. Bone Marrow Transplant $1991 ; 7: 489-91$.

8) Schuchter LM, Wingard JR, Piantadosi S, Burns WH, Santos GW, Saral R : Herpes zoster infection after autologous bone marrow transplantation. Blood $1989 ; 74: 1424-7$.

9) Verdonck LF, Cornelissen JJ, Dekker AW, Arska MR : Acute abdominal pains as a presenting symptom of varicellazoster virus infection in recipients of bone marrow transplants. CID $1993 ; 16: 190-1$.

10) McCluggage WG, Fox JD, Baillie KEM, Coyle PV, Jones FGC, O’ Hara MD : Varicella zoster gastritis in a bone marrow transplant recipient. J Clin Pathol $1994 ; 47: 1054-6$.

11) David DS, Tegtmeier BR, O’ Donnell MR, Paz IB, Mccarty TM : Visceral varicella-zoster after bone marrow transplantation : Report of a case series and review of the literature. Am J Gastroenterol $1998 ; 93: 810-3$.

12) Akiyama H, Inoue $T$, Okoshi $Y$, Mori S, Ohashi K, Maeda Y, et al . : Varicella-zoster virus infection after hematopoietic stem cell transplantation. Rinsho-ketsueki $1999 ; 41: 20-4$.

13) Hata A, Asanuma H, Rinki M, Sharp M, Wong RM, Blume K, et al .: Use of an inactivated varicella vaccine in recipients of hematopoietic-cell transplants. N Engl J Med $2002 ; 347: 26-34$.

14) Shepp DH, Dandliker PS, Meyers JD : Treatment of varicella zoster virus infection in severely immunocompromised patients. N Engl J Med $1986 ; 314: 208-12$.

15) Perren TJ, Powles RL, Easton D, Stolle K, Selby PJ : Prevention of herpes zoster in patients by long-term oral acyclovir after allogeneic bone marrow transplantation. Am J Med $1988 ; 85: 99-101$.

16) Carcao MD, Lau RC, Gupta A, Huerter H, Koren G, King SM : Sequentional use of intravenous and oral acyclovir in the therapy of varicella in immunocompromised children. Pediatr Infect Dis J $1998 ; 17: 626-31$.

17) Cohen JI, Brunell PA, Straus SE, Krause PR : Recent advances in varicella-zoster virus infection. Ann Intern Med $1999 ; 130: 922-32$.

18) Webster A, Grint P, Brenner MK, Prentice HG, Griffiths PD : Titration of IgG antibodies against varicella zoster virus before bone marrow transplantation is not predictive of future zoster. J Med Virol $1989 ; 27: 117-9$.

19) Wilson A, Sharp M, Koropchak CM, Ting SF, Arvin AM : Subclinical varicella-zoster virus viremia, herpes zoster, and T-lymphocyte immunity to varicella-zoster viral antigens after bone marrow transplantation. J Infect Dis 1992 ; 165 : $119-26$.

20) Redman RL, Nader S, Zerboni L, Liu C, Wong RM, Brown BW, et al . : Early reconstitution of immunity and decreased severity of herpes zoster in bone marrow transplant recipients immunized with inactivated varicella vaccine. J Infect Dis $1997 ; 176: 578-85$. 


\section{腹痛を初発症状とした全身性水痘感染症の 1 例}

\begin{tabular}{|c|c|c|c|}
\hline \multicolumn{4}{|c|}{ 媛大学医学部第 1 内科 } \\
\hline 若洋 & 源 & 陽子 & 高田 \\
\hline 冢 正樹 & 安川 & 正貴 & 藤田 \\
\hline
\end{tabular}

慢性 GVHD 治療中に原因不明の腹痛を初発と し, その後水疮形成, 公範な肝壊死, DIC, ARDS により死亡した全身性水痘帯状疮疹ウイルス （VZV）感染症を経験したので報告する，症例は $\mathrm{VZV}$ 抗体陽性の 36 歳男性. 1998 年 7 月 CMLに 対して allo BMT を施行. 移植後急性 GVHD に引 き続き慢性 GVHD を発症し, 当科にて加療を受け
ていた. 1999 年 9 月非麻薬性鎮痛剤のいずれにも 反応しない上腹部痛が出現し, 肝逸脱酵素の上昇 さらに体幹に表皮内小水疮が出現した．水疮内容 物から VZV 感染症と診断したが 3 日後に死亡し た. 免疫不全患者は全身性 VZV 感染症をきたす ことがあり,早期治療がなされねば致死的である. 初発症状としては上腹部痛が重要である. 